\title{
A Case Study on Empathic Tendency of Academicians in the Context of Interpersonal Relations
}

\author{
Müge YAZGAN, Ebru ÖZGEN \\ Marmara University, Istanbul, Turkey
}

\begin{abstract}
The originating of this study is to examine the empathic tendency of academicians. Having empathic tendency means it is easy to understand the feelings of the others and keeping up with the rapidly globalizing world. The research consists of screening model. The Scale of Empathic Tendency (SET), developed by Dökmen, was used as the data collection tool in this case study. In spite of not being taught, it is true that the education, cultural surroundings play a big role for the self development. Due to the relationship between impulse and response, interpersonal relations functions as multiple dimensions, one of which leads to empathic tendency. This study aims to make a survey on lecturers since they are the ones who play an important role for the pupils to be more successful in their future career. Total field under survey is 70 lecturers: Half of them are working at State and the other half at Private Universities in Istanbul, in Turkey. In spite of not observing big statistical differences between the two group Universities, according to Mann Whitney "U" test, it is so clear that having empathic tendency as lecturers affects classroom communication as the most important factor. This is the reason for the achievement of the students in their major. Furthermore, it gives an opportunity to get through the perception view of the others. This can give the perspective view of problem solving skills.
\end{abstract}

Keywords: empathy, empathic tendency, self development

\section{Introduction}

Society involves human beings and objects. Sociologists are concerned with the moving objects: people. In times, it is possible for a person to behave like the others around. In other words, a person unconsciously, puts himself in the place of the others and behaves as they do. Recently, it is so obvious that individuals are in more difficulty with interpersonal relationship due to the reduced correlation of empathy. Nevertheless, it must especially be emphasized that there is not only unique reason for this. According to Allport, attitude conceptually is a state of spiritual and neurological preparation on the behavior of the individual against the others with the result of experiences while leading a life (Freedman, Sears, \& Carlsmith, 1989, p. 2579). Obviously, Kağıtçıbaşı (1988, p. 123) describes the attitude as the transformation of habits into behavior. Each individual is born to an unfamiliar world around him. This uncertainty gets clearer with the relationship between him and his family members, relatives, and friends. Besides the education he takes, the cultural surroundings around and media make a border around him. In order to have a communication, one must know how to respond and how to react. Meaning is in the place where the answer is given. Gestures

Müge YAZGAN, MA, Lecturer, Faculty of Communication, Marmara University.

Ebru ÖZGEN, Associate Professor, Faculty of Communication, Marmara University. 
are helpful to express the feelings. Mead (1934, pp. 68-77), giving importance to the body language, considers talking with gestures is like a stimuli that keeps the meaning inside. While the meaning is in the place of the reply, body language helps to convey the emotions. For Wittgenstein (1967, pp. 35-50), language is a cipher, has meaning inside. On behalf of the greatest founder of structuralism Saussure, language and thought are always one to one corresponded with each other, cannot be separated. In fact, it should be known that expressions cannot be the sole domain of power; the discursions are the ones having the strength. In other words, discourses involve meaning among a group of individuals as common words are the addressing points. The thoughts are always described with the help of language (Güngör, 2013, pp. 213-215). While using the language, it is likely to take and give, to ask, to help. Providing that it is considered having a relationship between impulse and response, empathy is a skill to understand others and give responses by sharing their feelings (Cohen \& Strayer, 1996; Hoffman, 1987). To say, according to Rogers (1975, pp. 2-10), empathy is to understand the person opposite by putting oneself into his place. Fesbach is the first sociologist implying that empathy has multiple dimensions (Gini, Albiero, Benelli, \& Altoe, 2007). The multiple dimension empathy has empathic skill and emphatic tendency (Lawrence et al., 2004). By using emphatic skill, one is able to show the opposite that his feelings are understood. That is why, having this capacity means it is easier to put himself into the place of others. On the other hand, having emphatic tendency, one enables to understand the feelings of the others. It is the capability of having emotional tendency. In this case, positiveness, openness, supportiveness, equality, empathy (POSEE) are the qualitative components (Devito, 1992). Since it is innate and impossible to be changed, measuring the emotional tendency is the only way to see the potential of the individual in daily life. Nowadays, the only key to have an achievement is to be aware of the active communication and to reach the target; that is why, so as to be helpful for the public it is necessary to get away from the prejudice, dictations; instead to be understandable and to be compromiser are more accelerating for the closer relationships. By taking all these above into consideration, a classification based on the causes in the direction of the outcomes wished to be made within the topic "Empathic Evaluation of Academicians".

\section{Theoretical Framework}

The differences between understanding, perceiving and interpreting can cause a conflict in interpersonal relationship. While having good empathy, leading successful perception, one is able to have a healthy relationship with the others. Nowadays, communication needs filling the vacancy of the solutions while having more disagreement among the people. To have a healthy relationship, the tools for communication must be enhanced well. Especially, due to the obligatory relations at the organizations and in working areas, each should take the essential role to overcome all the difficulties faced. Here the most important issue is to identify how to utter from the determined expressions. The trouble in communication observed in our society results from the differences in thoughts, notions, and ideas among the generations. It is known that the young are in difficulty explaining their problems in front of the public, feeling insecure among the others owing to getting deactivated by the elders, having no chance to defend themselves while debating (Yeşilyaprak, 1986, p. 82). Here the most important role is the academicians: they are the ones who play an important role for the young to find themselves. In other words, the way that they demonstrate gives alternative ways to follow for their future career. 
The present study aims to expand current knowledge on emphatic relationship and to compare the emphatic tendency of academicians working in the state universities with the academicians hired by the private ones.

\section{Having Emphatic Tendency}

Besides political, cultural and economic needs, technological and economic changes in the world have influenced the people all over the world. Due to the rapid progress in communication and high development in the tools, an increasing need for empathy is felt to keep up with the rapidly globalizing world. The young are given more chance to express themselves than they used to. What is more, having both emphatic skill and emphatic tendency as an academician leads the young to be more achieved in their research and progress. Classes are not predominantly teacher-centered anymore, the lessons are done interactively. Hardworking is by no means enough for the students to get higher grades. It is clear that the young who may take the right decisions, depending on circumstances, who may predict, who may empathize the next to gain their identifications with the situation, may have the advantage to succeed sooner than the others in life. Therefore, academicians should empathize with their students and their assistants as well. Although there have not been any formal evaluation studies, it is a well known fact that for the university students, the emphatic tendency of the academicians plays a great role.

\section{Method}

\section{Participants \& Setting}

The study is in a screening model, intending to examine the Emphatic Tendency levels of the lecturers in private and state universities for the point of various variables. The participants in this study were thirty five academicians in each group; thirty five academicians from the state universities, thirty five academicians from the private universities; totally seventy.

The academicians are all at the universities in Istanbul. They all have been working at different departments for at least five years. Most of them had the opportunities to make a research or an observation abroad at least once. They all had graduated from the universities in Turkey. What is more, they are all experts in their fields.

\section{Data Collection Tools and Analysis}

As being a likert type scale, the two groups were compared in "the Scale of Emphatic Tendency" (SET) developed by Dökmen. It is developed with the intention of measuring the individuals' potential to develop empathy in their daily lives (Dökmen, 1988, pp. 155-190). It is composed of 20 questions, graded from 1 to 5 per each. While summing up, 3rd, 6th, 7th, 8th, 11th, 12th, 13th, 15th questions are put into reverse order. The lowest scale is 20 , and the highest is 100 . The overall point represents the empathic tendency point of each participant.

Since the scale has been developed with a view to measure the individual potential to realize empathy in daily life, the mean and standard deviation are computed to analyze the data statistically. The statistical significance level is selected as 0.05 .

An investigation is done on levels of the emphatic tendencies of elite university academicians in terms of different variables. According to the overall point, the higher one means, the higher the empathic tendency is and vice versa. Reliability of the scale, upon the conducted analysis, is found as 0.82 . 


\section{Limitations}

It is essential to emphasize that the limitations have involved in this research. Firstly, the limited number of the participants in this study has restricted the ability to draw strong generalizations. Further research with a greater number of lecturers working in different cities of Turkey is needed to find out the effects of empathic tendency on pupils. Secondly, an experimental design examining the relationships could lead to stronger casual conclusions. For example, making an interview can give an opportunity to have stronger casual conclusions. To sum up, in spite of its limitations it has been beneficial in underscoring the importance of empathic tendency of the academicians according to their genders and the type of the universities they work at.

\section{Results}

Table 1

The Results of Mann Whitney "U" for the Total Values of Empathy According to the Different Types of Universities

\begin{tabular}{lllllll}
\hline The total values of empathy & $N$ & $\sum_{\text {sira }}$ & $\bar{x}_{\text {sira }}$ & $U$ & $z$ & $p$ \\
\hline Private & 35 & 36.27 & 1269.50 & & & \\
State & 35 & 34.73 & 1215.50 & 585.500 & -0.318 & 0.751 \\
Total & 70 & & & & \\
\hline Notes. ${ }^{*} p<0.05 ;{ }^{* *} p<0.01 ;{ }^{* * *} p<0.001$.
\end{tabular}

According to the results of Mann Whitney "U" (Benferonni Correction) from complementary calculations made on the basis of empathy total values in Table 1, for the "Private" and "State" college variants, there exhibits no big statistical differences in terms of the variety of universities $(p<0.05)$. However, when the two types of universities are compared, it is clear that private ones are higher in average order.

Where:

$P=$ significance ${ }^{*} p<0.05$ significance level; ${ }^{* *} p<0.01=$ high level significance; ${ }^{* * *} p<0.001=$ highest level sig.

$\sum_{\text {sira }}=$ sampling order value; $\bar{x}_{\text {sira }}=$ Average order value;

$Z=$ direction "-" significance in the direction of "State Universities".

Table 2

Total Grade and Percentage Distributions Regarding the Genders of the Research Group

\begin{tabular}{llclcc}
\hline State Universities & Total Grade & Percentage & Private Universities & Total Grade & Percentage \\
\hline Female Lecturers & 1,353 & $52.8 \%$ & Female Lecturers & 1,333 & $51.4 \%$ \\
Male Lecturers & 1,211 & $47.2 \%$ & Male Lecturers & 1,262 & $48.6 \%$ \\
& 2,564 & $100.0 \%$ & & 2,595 & $100.0 \%$ \\
\hline
\end{tabular}

To find whether there are differences between the two groups according to their genders from private and state universities, we took the percentages of empathic tendency points for each group. The table provides a breakdown by genders on summed up total grade and percentages form the obtained results. As can be seen in Table 2, there are roughly equal proportions between the universities: $52.8 \%$ and $51.4 \%$ for females and $47.2 \%$ and $48.6 \%$ for males. However, there is a slight difference when the genders are considered: $52.8 \%$ for females while $47.2 \%$ for males at the state universities and $51.4 \%$ for females while $48.6 \%$ for males at the private universities. 
As being understood from the data being obtained from the Table 2: The female lecturers have more empathic tendency than male lecturers at both types of universities. However, while the average point of female lecturers at the state universities are higher, the average point of male lecturers at the private universities get more score when compared with the male lecturers at the state universities.

Table 3

The Average Points of the Genders in the Research Group

\begin{tabular}{llll}
\hline State Universities & Average Points & Private Universities & Average Points \\
\hline Female Lecturers & 79.5 & Female Lecturers & 78.4 \\
Male Lecturers & 67.2 & Male Lecturers & 70.0 \\
\hline
\end{tabular}

\section{Table 4}

The Average Points of the Total Research Groups at Both Types of Universities

\begin{tabular}{ll}
\hline & Average Points \\
\hline State Universities & 73.2 \\
Private Universities & 74.0 \\
\hline
\end{tabular}

According to the result taken from both types of universities, it is clear that both of the lecturers attending to the research have empathic tendency due to having a rising point towards 80 .

Table 5

Total Grade and Percentage Distributions of Each Research Group

\begin{tabular}{|c|c|c|c|c|c|c|}
\hline Research Groups & $\begin{array}{l}\text { Total of positive } \\
\text { grade }\end{array}$ & Percentage & $\begin{array}{l}\text { Total of negative } \\
\text { grade }\end{array}$ & Percentage & Total & Total percentage \\
\hline State Universities & 1,569 & $61.2 \%$ & 995 & $38.8 \%$ & 564 & $100 \%$ \\
\hline Private Universities & 1,604 & $61.8 \%$ & 991 & $38.2 \%$ & 595 & $100 \%$ \\
\hline
\end{tabular}

The table provides a breakdown by selected research groups of those on total of positive and negative groups with their percentages taken. We took the reversed sum as the total of negative grade. As can be observed from the results, there is no considerable difference between them. The results for both universities are so near to each other.

\section{Discussion}

Empathy is the process of feeling and thinking by setting yourself into the place of someone else (Stein, 1970). Empathy seems to be an important perspective in educational studies. Duru (2002) in a study aimed to examine the difference between empathic tendency scores of the candidate students. Out of the total 402 students, the results show that empathic tendency is related to gender. In other words, several researchers (Yılmaz \& Akyel, 2008; Dökmen, 1988; Toy, 2007; Chung \& Bemak, 2002) maintained that communication was the first condition of empathy. The present study aims to find out the implications of empathic tendency among academicians. In this study, empathic tendency levels of the participated academicians are observed by using empathic tendency scale developed by Dökmen (1988). It is unlikely to teach empathic behaviors directly to individuals. However, self-awareness can be increased by setting an alternative. What is more, the present study has shown that the female lecturers get higher scores than the male colleagues. It is significantly true that a teacher plays an important role in motivating the learners. As an educational facilitator and social mediator, encouraging the students for their future career is the duty of the lecturers. 


\section{Conclusion}

Empathic tendency is an important factor that affects classroom communication. It is impossible not to have any communication while sharing the same physical conditions. It is obvious that the success of the students and the acceleration of the getting expertised at universities could be seen more when there is empathic tendency (Özodaşık, 2009, pp. 21-30). By having empathic tendency, it is possible to get through the perception view of the others (Yıldırım, 2005, p. 32). Here, it is essential to see how the others consider the outside world and how they make a comment on it. In order to consolidate this idea, Uncertainty Reduction Theory of Berger and Calabrese (1975) can be examined. It says it is possible to focus on the others by having self-awareness. One way to have this capacity is that the lecturers should be given chance to have their initiative feelings. Otherwise, it is so hard to be optimistic as an individual. The other way is studying on personal development, problem solving skills. These enable the academicians not only to increase interaction with their students but also help to direct them in their future career correctly. Yet, in order to generalize the results, further research is required. Especially, the research in different cities in Turkey can give different perspectives on the further study.

\section{References}

Berger, C., \& Calabrese, R. (1975). Some exploration in initial interaction and beyond: Toward a developmental theory of interpersonal communication. Human Communication Research, 1(2), 99-112.

Chung, R., \& Bemak, F. (2002). The relationship of culture and empathy in cross-cultural counseling (practice and theory). Journal of Counseling Development, 80, 154-156.

Cohen, D., \& Strayer, J. (1996). Empathy in conduct-disordered and comparison youth. Developmental Psychology, 32, 988-998.

Devito, J. (1992). The interpersonal communication book (6th ed.). New York: Harper Collins.

Dökmen, Ü. (1988). Empatinin bir modele dayandırılarak ölçülmesi ve psikodrama ile geliştirilmesi (Measuring empathy based on a model and developing by psychodrama). Ankara Üniversitesi Eğitim Bilimleri Fakültesi Dergisi (Journal of Ankara University Faculty of Education), 62(21), 155-190.

Dökmen, Ü. (1990). Yeni bir empati modeli ve empatik becerinin iki farklı yaklaşımla ölçülmesi (A new empathy model and measurement of empathic skill by two different approaches). Psikoloji Dergisi (Journal of Psychology), 7(24), 42-50.

Duru, E. (2002). Öğretmen Adaylarında Empatik Eğilim Düzeyinin Bazı Psikososyal Değişkenler Açısından İncelenmesi (Evaluation of empathic tendency level of teacher candidates in terms of some psychosocial variables). Pamukkale Üniversitesi Eğitim Fakültesi Dergisi (Journal of Pamukkale University Faculty of Education), 12, 21-35.

Freedman, J. L., Sears, D. O., \& Carlsmith, J. M. (1989). Sosyal Psikoloji (Çev. Ali Dönmez). İstanbul: Ara Yayınları.

Gini, G., Albiero, P., Benelli, B., \& Altoe, G. (2007). Does empathy predict adloscents' bullying and defending behaviour? Aggressive Behavior, 33(5), 467-476.

Güngör, N. (2013). Iletişim Kuramlar ve Yaklaşımlar (Communication Theories and Approaches). Ankara: Siyasal Kitabevi.

Hoffman, M. L. (1987). The contribution of empathy to justice and moral judgment. In N. Eisenberg, \& J. Strayer (Eds.), Empathy and its development (pp. 47-80). Cambridge, England: Cambridge University Press.

Kağıtçıbaşı, E. (1988). Insan ve İnsanlar (Person and people). İstanbul: Evrim Basım Yayıncılık.

Lawrence, E. J., Shaw, P., Baker, D., Baron-Cohen, S., \& David, A. S. (2004). Measuring empathy: Reliability and validity of the Empathy Quotient. Psychological Medicine, 34, 911-924.

Mead, G. H. (1934). Mind, self and society: From the standpoint of a social behaviorist. Chicago: The University of Chicago Press.

Özodaşı, M. (2009). Algı - İkna ve Empatik İlişkiler (Perception - Persuasion and Empathic Relations). Konya: Tablet Yayınları.

Rogers, C. R. (1975). Empathic: An unappreciated way of being. Counseling Psychologist, 5(2), 2-10.

Stein, E. (1970). On the problem of empathy (2nd ed.). The Hague, The Netherlands: Matinus Nijhoff / Dr. W. Junk Publishers.

Toy, S. (2007). Comparisons of engineering and law students in terms of their communication skills and the relationships between communication skills and some variables (Ankara University Social Sciences Institution, Master's Thesis).

Wittgenstein, L. (1967). Philosophical Innovations (3rd ed.). New York: Macmillian. 
Yeşilyaprak, B. (1986). Üniversite Gençliğinin Psikolojik Sorunları (Psychological problems of the university students). Psikoloji Dergisi (Journal of Psychology), Say1 20 (Volume 20).

Yıldırım, A. (2005). Empati ve Çatışmalar (Empathy and conflicts). Ankara: Yargı Yayınevi.

Y1lmaz, İ., \& Akyel, Y. (2008). Examination of empatic tendency levels of physical education candidates teacher in terms of different variables. Ahi Evren Üniversitesi Kırşehir Eğitim Fakültesi Dergisi, 9(2), 27-33. 